\title{
Physicochemical Properties of the Seed Kernels and the Oil of Custard Apple (Annona squamosa L.)
}

\author{
Dalia H. Eshra ${ }^{1}$, Attia R. Shehata ${ }^{1}$, Abdel-Nabey A. Ahmed ${ }^{1}$, Jehan I. Saber ${ }^{2, *}$ \\ ${ }^{1}$ Food Science and Technology Department, Alexandria University, Alexandria, Egypt \\ ${ }^{2}$ Home Economics Department, Alexandria University, Alexandria, Egypt
}

Email address:

jeje_saber2000@yahoo.com (J. I. Saber)

${ }^{*}$ Corresponding author

\section{To cite this article:}

Dalia H. Eshra, Attia R. Shehata, Abdel-Nabey A. Ahmed, Jehan I. Saber. Physicochemical Properties of the Seed Kernels and the Oil of Custard Apple (Annona squamosa L.). International Journal of Food Science and Biotechnology. Vol. 4, No. 4, 2019 , pp. 87-93. doi: $10.11648 /$ j.ijfsb.20190404.12

Received: July 7, 2019; Accepted: October 22, 2019; Published: November 19, 2019

\begin{abstract}
Custard apple (Annona squamosal L.) seed kernel and the extracted oil were characterized for their physicochemical properties. Crude ether extract was found to be the main component where, the seed kernels had $31.22 \%$. Moreover, protein content was $20.01 \%$. On the other hand, the crude fiber and total ash were 15.43 and $1.89 \%$, respectively. Total phenolic compounds, antioxidant activity and $\mathrm{IC}_{50}$ of CASKF were $42.02 \mathrm{mg} \mathrm{GAE} / 100 \mathrm{~g}, 87.55 \%$ and $22.84 \mu \mathrm{g} / \mathrm{ml}$, respectively. The results indicated that CASKF is rich in content of $\mathrm{K}, \mathrm{P}, \mathrm{Ca}, \mathrm{Mg}$ and $\mathrm{Na}$. Nevertheless, very low levels of $\mathrm{Cd}$ and $\mathrm{Pb}$ were detected. The amino acid composition of the defatted CASKF indicated that glutamic, aspartic, alanine, leucine and arginine were the predominant amino acids. The total amount of essential amino acids in the defatted CASKF was $37.77 \mathrm{~g}$ $/ 100 \mathrm{~g}$ protein (-) which is higher than that reported in FAO/ WHO pattern. The dominant fatty acids of custard apple seed kernel oil were oleic $(49.75 \%)$, Linoleic $(22.50 \%)$, palmitic $(15.06 \%)$ and stearic and $(4.63 \%)$. The oil could be classified as a semi-dry oil. Total lipid fractions consisted mainly of nine classes in which triacylglycerols were the major class.
\end{abstract}

Keywords: Custard Apple, Annona Squamosa, Chemical Composition, Oil Characteristics.

\section{Introduction}

The custard apple (Annona squamosa L) from Annonaceae family a fruitful in equatorial and semitropical areas, adapted to the climatic states of China, Africa, South America, Australia, India, Mexico, (-)United states, Thailand and Egypt. Increase consumption of custard apple is related to the medicinal and nutritional properties, as well as its pleasant flavor. The fruit is rich in vitamins $\mathrm{A}, \mathrm{B}, \mathrm{C}, \mathrm{E}$ and $\mathrm{K}$, antioxidants, polyunsaturated fatty acids and the presence of essential minerals. In addition, this fruit included assortment of compounds which are responsible for antifeedant, antimalarial, cytotoxic, immuno suppressive, anti HIV and antiplatelet aggregation activities [1,2]. The fruit is easily broken or cut open, uncover the snow-white, Juicy flesh, of pleasant flavor and delicious, sub-acid flavor and containing many hard, brown or black bean-like glossy seeds [3]. Many domestic names have developed for the fruit. In English, it is most vastly known as sugar apple or sweetsop as well as a custard apple. In the middle East, it is called qishta, ishta or ashta [4]. Custard apple fruits are convenient for treatment because of its high sugar content and delicate flavor. The fruit is marketed as fresh or frozen pulp, strained juice and frozen concentrates which have been preserved as various juice blends, ice cream, sherbets and nectars [3].(-) The seeds have major insecticidal properties and could be used for removing head lice [5]. The seeds are also utilized as a pesticide in the field of agriculture [6], or have antimicrobial properties [7-9]. In addition, Koushik et al. [10] stated that the extracts of custard apple seeds could also be included in drugs that treat inflammation caused by fungi.

(-)Sugar apple seed oil can be used to produce biodiesel [11]. There was no interest from food processing workers in the use of Egyptian custard apple seeds (Annona squamosa L.) or oil extracted from the seeds in food processing.

Therefore, in this study physical properties, chemical composition, total phenolic compounds and antioxidant 
activity of seed kernels of Egyptian custard apple were studied.

In addition, some physical and chemical properties of oil extracted from seed kernels were evaluated. This study is therefore of great importance in assessing the nutritional value of custard apple seed kernels and its extracted oil.

\section{Materials and Methods}

\subsection{Materials}

Custard apple (Annona squamosal L) fruits were procured from the local market of Alexandria, Egypt. The fruits studied were in full maturity. The fruits were washed with running water then sliced and the seeds were separated with a steel spoon. The seeds were collected and cleaned from the residue of fruit, then washed completely with distilled water and air dried. The dried seeds were manually dehulled with a sharp knife. The resultant seed kernels were ground and sieved through 60 mesh sieve. The obtained flour (CASKF) was stored in tightly Kilner jar at $4 \pm 2^{\circ} \mathrm{C}$ until used. Figure 1 shows the general appearance of custard apple fruit, cross section and the seeds.

\subsection{Chemicals}

All chemicals used were of analytical grade and were purchased from El-Gamhouria Co. for Chemical and Medical Requistes, Alexandria, Egypt. DPPH reagent (1,1- diphenyl2- picrylhydrazyl) was obtained from Sigma Company, Germany.

\subsection{Methods}

Physical properties including seed index, bulk density, hull and kernel percentages and seed dimensions including length, width and thickness were determined [12]. Proximate analysis of CASKF including moisture, crude protein $(\mathrm{N} \mathrm{x}$ 6.25), crude ether extract, total ash and crude fiber were carried out according to AOAC [13]. procedures unless otherwise stated. Nitrogen free extract (NFE) was calculated by difference. Total phenolic compounds were determined by Folin- Ciocaltu reagent [14] after extraction with $70 \%$ ethanol [15].

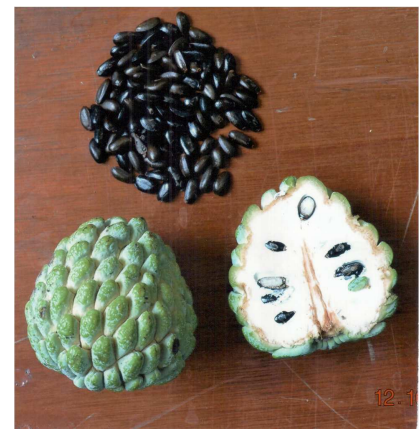

Figure 1. General appearance and cross section of custard apple (Annona squarnosa $\mathrm{L}$.) fruit and the seeds.

\subsection{DPPH Radical Scavenging Activity}

Antioxidant activity was estimated by assessing the free radical activity of the 1,1- Diphenyl-2-picryl-hydrazyl (DPPH) radical [16]. (-) $0.3 \mathrm{ml}$ methanolic extract was added to $2.7 \mathrm{ml}$ DPPH $0.1 \mathrm{mmol}$ in methanol solution. Then the reaction mixture was well mixed and incubated for approximately $30 \mathrm{~min}$ at room temperature in the dark. Absorbance was measured at $517 \mathrm{~nm}$ using a UV-Vis Spectrophotometer. The antioxidant activity was calculated as a percentage of inhibition DPPH from the following equation:

$$
\text { Inhibition }(\%)=\frac{\text { A DPPH-A sample }}{\text { A DPPH }} x 100
$$

Where: A sample is the absorbance of sample.

A DPPH is the absorbance of the control (DPPH solution).

The $\mathrm{IC}_{50}$ is defined as the concentration of antioxidant necessary to decrease the initial DPPH concentration by $50 \%$. The $\mathrm{IC}_{50}$ of the sample was derived from the $\%$ scavenging activity vs. concentration plot and is expressed as $\mathrm{mg} / \mathrm{ml}$.

\subsection{Minerals and amino acids}

$\mathrm{Fe}, \mathrm{Mg}, \mathrm{Ca}, \mathrm{Zn}, \mathrm{Cu}, \mathrm{Mn}, \mathrm{Cd}$ and $\mathrm{Pb}$ were estimated using Perkin Elmer Atomic Absorption Spectrophotometer, while, $\mathrm{Na}$ and $\mathrm{K}$ were determined using flame photometer. Total phosphorus $(\mathrm{P})$ was assayed colorimetrically at $630 \mathrm{~nm}$ using a Spectrophotometer [13]. Amino acids were analyzed in the hydrolyzate using Amino Acid Analyzer (Biochrom 30). Amino acid composition were expressed, as $\mathrm{g} / 100 \mathrm{~g}$ protein. Tryptophan was (-)colorimetrically determined in the alkaline hydrolysate [17]. Amino acid score (AAS) was calculated from the essential amino acid (EAA) content to the total EAA content in $1 \mathrm{~g}$ sample protein divided by the same EAA content in the reference FAO/ WHO [18] pattern. From the AAS, the limiting AA in the sample which had the lowest values AAS could be established [18].

\subsection{Lipid Profile}

Chloroform: methanol $(2: 1)$ was used to extract the total lipids [19]. The total lipid extract was divided into different classes using a TLC method [20] on glass plates $(20 \times 20 \mathrm{~cm})$ pre-coated and loaded with $0.25 \mathrm{~mm}$ silica gel, G-60. The rising solvent system used was petroleum ether: diethyl ether: glacial acetic acid (70:30:2 V/V/V). After completing the solvent rise process, the plate was air-dried and the separated spots were shown by iodine vapor. Lipid categories were determined by their $\mathrm{R}_{\mathrm{f}}$ values [21].

\subsection{Fatty Acid Composition}

(-)Fatty acid methyl esters utilizing 1\% sulphuric acid in absolute methanol were prepared [22]. Gas chromatographic analysis was carried out using ACME. Equipped with a splitless injector and flame ionization detector. Nitrogen was used as a carrier gas. The components were separated on a 
30-cm Sp-2380 fused- silica capillary column. The detector temperature was set at $260^{\circ} \mathrm{C}$. The injector temperature was set at $220^{\circ} \mathrm{C}$ and in split mode (Split ratio 80:1). Total program time was $30 \mathrm{~min}$. Fatty acid composition was expressed as percentage of the total fatty acids.

Identity properties of the oil extracted from CASKF Which included refractive index (RI) at $25^{\circ} \mathrm{C}$, Specific gravity (Sp. $\mathrm{Gr}$ ) at $25^{\circ} \mathrm{C}$, iodine value (IV), saponification value (SV), peroxide value ( $\mathrm{PV}$ as $\mathrm{mEq} \mathrm{O}_{2} / \mathrm{kg}$ ) free fatty acid (FFA) as\% oleic acid, unsaponifiable matter (\%) and color measured by using Lovibond Tentometer were determined [23].

\subsection{Statistical Analysis}

SPSS software was used to calculate percentages, arithmetic averages and standard deviation [24].

\section{Results and Discussion}

Physical properties of custard apple fruits, seeds and seed kernels.

Physical properties of custard apple fruits, its seeds and seed kernels are shown in (Tables 1 and 2). It can be noted that fruit weight was $141.25 \mathrm{~g}$. On the other hand, the weight of pulp, hulls and seeds were 77.24, 32.08 and $18.71 \mathrm{~g}$, respectively which represented $54.68,32.08$ and $18.71 \%$, respectively of the total weight of the fruit. Kad et al. [12] found that the weight of fruit was $238.68 \mathrm{~g}$. Also they found that peel, capillary pulp, gritty pulp and seeds were 46.77 ,

\section{$35.36,11.63$ and $6.24 \%$, respectively.}

As shown in (Tables 1 and 2), seed weight, seed index and bulk density of custard apple seeds (CAS) were 0.2649, 26.44 (g/100g seeds) and $0.49 \mathrm{~g} / \mathrm{cm}^{3}$. After dehulling, these values were $0.209 \mathrm{~g}, 20.896$ (g/100 seed kernel) and $0.504 \mathrm{~g} / \mathrm{cm}^{3}$, respectively. The data also indicated that CAS dimensions (length, width and thickness) were 1.519, 0.704 and $0.514 \mathrm{~cm}$ ), respectively. On the other hand, after dehulling these values decreased to $1.148,0.554$ and $0.464 \mathrm{~cm}$, respectively. The percentages of hulls and kernels of CAS were 33.50 and $66.5 \%$, respectively. Comparing with the results obtained in the present study, Kad et al. [12] found that length, breath and thickness of annona squamosa seeds were 13.69, 8:29 and 6.1 $\mathrm{mm}$, respectively at the initial moisture content $(15.40 \%$ d.b.) and decreased with decrease in moisture content to 12.50 and $10.25 \%$ (d.b.) They mentioned that the bulk density, was 0.642 $\mathrm{g} / \mathrm{cm}^{3}$. This value increased to 0.661 and $0.684 \mathrm{~g} / \mathrm{cm}^{3}$ when the moisture content decreased from $15.4 \%$ to 12.5 and $10.25 \%$.

Table 1. Physical properties of custard apple (Annona squamosal L.) fruit.

\begin{tabular}{ll}
\hline Property & Value* \\
\hline Weight of fruit $(\mathrm{g})$ & $141.25 \pm 3.06$ \\
Weight of hull $(\mathrm{g})$ & $45.31 \pm 1.62$ \\
$\%$ of hull & $32.08 \pm 1.35$ \\
Weight of pulp $(\mathrm{g})$ & $77.2 \pm 2.06$ \\
$\%$ of pulp & $54.68 \pm 1.63$ \\
Weight of seeds $(\mathrm{g})$ & $18.71 \pm 0.54$ \\
$\%$ of seeds & $13.24 \pm 0.82$ \\
\hline
\end{tabular}

* Mean of three determinations $\pm \mathrm{SD}$.

Table 2. Physical properties of custard apple seeds and kernels.

\begin{tabular}{lll}
\hline Property & Seeds & Kernels \\
\hline Weight of seed or kernel $(\mathrm{g})$ & $0.264 \pm 0.001$ & $0.209 \pm 0.07$ \\
seed or kernel index $(\mathrm{g} / 100$ seed or kernel) & $26.44 \pm 1.03$ & $20.896 \pm 0.073$ \\
Bulk density $\left(\mathrm{g} / \mathrm{cm}^{3}\right)$ & $0.487 \pm 0.03$ & $0.504 \pm 0.006$ \\
Seed dimensions $(\mathrm{mm})$ & & $11.48 \pm 0.03$ \\
Length & $15.19 \pm 0.02$ & $5.54 \pm 0.02$ \\
Width & $7.04 \pm 0.01$ & $4.64 \pm 0.01$ \\
Thickness & $5.14 \pm 0.01$ & \\
Hull\% & $33.50 \pm 1.63$ & \\
Kernels\% & $66.50 \pm 1.82$ & \\
\hline
\end{tabular}

* Mean of three determinations $\pm \mathrm{SD}$.

A proximate chemical composition, total phenolic contents and antioxidant activity of CASKF are shown in (Table 3 ). Crude ether extract of CASKF was found to be the main component. The seed kernels had $31.22 \%$ crude ether extract. This high content of oil reflects the importance of using such seed kernels for oil production. On the other hand, CASKF had about $20.01 \%$ crude protein, which possessed medium concentration between cereals, legumes and other oilseeds. It can be also noted that CASKF contained $15.43 \%$ crude fiber. Removal of hulls reduced the fiber content and thus concentrate both the crude oil and protein. The data in Table 3 revealed also that total ash content of CASKF was $1.89 \%$. On the other hand, the calculated NFE was $31.45 \%$. Comparing with the results obtained in the present study, Hassan et al. [25] found that on dry weight bases, ash contend, crude lipid, crude protein, crude fiber and available carbohydrate contents were 2.78, 44.0, 4.43, 36.33 and $12.45 \%$, respectively. Further, Mariod et al. [26] stated that the oil and protein contents of Annona squamosa seeds were 26.8 and $17.5 \%$, respectively. Furthermore, Mariod et al. [27] found that Annona squamosa seeds had $6.7 \%$ moisture, $26.8 \%$ fat, $17.5 \%$ protein, $2.2 \%$ ash, $16.8 \%$ fiber and $30.0 \%$ carbohydrates. Also, Shardul et al. [28] found that the seeds of Annona squamosa contained $1.22 \%$ moisture by KarlFischer method and $1.46 \%$ by loss on drying method. The total ash content was $2.39 \%$. The results in Table 3 showed that CASKF contained considerable concentration of phenolic compounds being $42.02 \mathrm{mg} \mathrm{GAE} / 100 \mathrm{~g}$. It has been reported that CASKF contained different type of phenolics. These compounds had anticancer effects [29]. 
The results in Table 3 also showed that CASKF had high percentage of antioxidant activity being $87.55 \%$. These results confirmed the possibility of using CASKF as an antioxidant source. $\mathrm{IC}_{50}$ of CASKF was $22.84(\mu \mathrm{g} / \mathrm{ml})$. In accordance with the results obtained in the present study, Kothari and Seshadri [30] and Biba et al. [2] stated that the seed extract of Anniona squamosa showed highest antioxidant activities and phenolic content. The seeds may be a good source of antioxidants that may have therapeutic uses. Kadarani et al. [31] found that seeds of Annona squamosa had higher total phenolic concentration and antioxidant activity than the peels of this fruits. Vijayaraghavan et al. [32] showed that the seeds of Annona squamosa recorded the most effective DPPH radical scavenging activity (77.14\%) being close to synthetic antioxidant (BHT) as positive control $(76.3 \%)$ This is because the seed extract of Annona squamosa was rich in glycosides, alkaloids, phenols, tannins and saponins.

Table 3. Proximate chemical composition, total phenolis and antioxidant activities of custard apple seeds kernel flour.

\begin{tabular}{ll}
\hline Component & Value* \\
\hline Moisture (\%) & $6.80 \pm 0.30$ \\
Crude ether extract (\%) & $31.22 \pm 1.27$ \\
Crude protein (\%) & $20.01 \pm 0.73$ \\
Total ash (\%) & $1.89 \pm 0.02$ \\
Crude fiber (\%) & $15.43 \pm 1.66$ \\
Nitrogen free extract $(\%)^{* *}$ & $31.45 \pm 0.89$ \\
Total phenolic content $(\mathrm{mg} \mathrm{GAE} / 100 \mathrm{~g})$ & $42.02 \pm 0.13$ \\
Antioxidant activity $(\%)$ & $87.55 \pm 1.23$ \\
$\mathrm{IC}_{50}(\mu \mathrm{g} / \mathrm{ml})$ & $22.87 \pm 0.43$ \\
\hline
\end{tabular}

* Mean of three determinations \pm SD (on dry weight basis).

** By difference.

Mineral content of CASKF are shown in (Table 4). As shown in the Table, CASKF is a good source of macro elements such as $\mathrm{k}, \mathrm{P}, \mathrm{Ca}, \mathrm{Mg}$ and $\mathrm{Na}$. low levels of $\mathrm{Fe}, \mathrm{Zn}$, $\mathrm{Mn}$ and $\mathrm{Cu}$ were present. On the other hand, very low levels of $\mathrm{Cd}$ and $\mathrm{Pb}$ were also detected. The aforementioned data are more or less in accordance with those reported by Amoo et al. [33], Hassan et al. [25] and Souza et al. [34]. The latter showed that the mineral composition of flour from residual Annona squamosa responds to more than $20 \%$ of the daily intake of nutrients, highlighting the $\mathrm{Cu}, \mathrm{Fe}, \mathrm{Mn}, \mathrm{Zn}, \mathrm{Ca}$ and $\mathrm{Mg}$.

Table 4. Mineral content of custard apple seed kernel flour.

\begin{tabular}{ll}
\hline Element & $\mathbf{m g} / \mathbf{1 0 0 \mathbf { g } ^ { * }}$ \\
\hline $\mathrm{K}$ & $363 \pm 9.56$ \\
$\mathrm{Mg}$ & $98 \pm 6.63$ \\
$\mathrm{Na}$ & $61 \pm 1.88$ \\
$\mathrm{Ca}$ & $280 \pm 8.31$ \\
$\mathrm{Zn}$ & $2.84 \pm 0.23$ \\
$\mathrm{P}$ & $328 \pm 4.21$ \\
$\mathrm{Cu}$ & $1.09 \pm 0.23$ \\
$\mathrm{~Pb}$ & $0.38 \pm 0.003$ \\
$\mathrm{Fe}$ & $3.05 \pm 0.17$ \\
$\mathrm{Mn}$ & $2.93 \pm 0.31$ \\
$\mathrm{Cd}$ & $0.13 \pm 0.005$ \\
\hline
\end{tabular}

* Mean of three determinations $\pm \mathrm{SD}$ (on dry weight basis).

Amino acid composition of the defatted CASKF is presented in (Table 5). The results indicated that the predominant amino acids were glutamic (13.13), aspartic (9.03), alanine (7.84), leucine (7.15) and arginine 6.29 $\mathrm{g} / 100 \mathrm{~g}$ protein. Relatively, small amount of the other amino acids listed in Table 5 were also found. Table 5 also found that the total amount of essential amino acids in the defatted CASKF was $37.77 \mathrm{~g} / 100 \mathrm{~g}$ protein. The results indicated that the protein of the defatted CASKF is deficient in methionine and lysine as compared with $\mathrm{FAO} / \mathrm{WHO}$ requirement pattern (Table 5). Thus, the first limiting amino acid was methionine and lysine. The obtained results agreed well with those reported by Mariod et al. [26, 27]. They reported that the amino acid content of Annona squamosa seeds showed a high difference when compared with egg, sesame and broad bean amino acids. They also reported that all the essential amino acids with the exception of tryptophan were found to be present in high amounts when compared to that of the three different foods mentioned above.

Table 5. Amino acid composition and chemical score of defatted custard apple seed kernel.

\begin{tabular}{|c|c|c|c|}
\hline Amino acid (g/100g protein)* & Value & FAO/WHO pattern** & Chemical score $* * *$ \\
\hline Aspartic acid & $9.03 \pm 0.30$ & & \\
\hline Threonine & $4.28 \pm 0.10$ & 3.40 & 125.88 \\
\hline Serine & $3.95 \pm 0.20$ & & \\
\hline Glutamic acid & $13.13 \pm 0.50$ & & \\
\hline Proline & $5.68 \pm 0.12$ & & \\
\hline Glycine & $5.17 \pm 0.10$ & & \\
\hline Cystine & $1.09 \pm 0.12$ & & \\
\hline Methionine & $2.31 \pm 0.10$ & 2.50 & $92.40+$ \\
\hline Cystine + Methionine & $3.40 \pm 0.10$ & & \\
\hline Valine & $4.47 \pm 0.20$ & 3.50 & 127.71 \\
\hline Isoleucine & $3.12 \pm 0.20$ & 2.80 & 111.43 \\
\hline Leucine & $7.15 \pm 0.30$ & 6.60 & 108.33 \\
\hline Tyrosine & $3.45 \pm 0.20$ & & \\
\hline Tryptophan & $1.38 \pm 0.12$ & 1.10 & 125.45 \\
\hline Histidine & $1.83 \pm 0.10$ & 1.90 & 96.32 \\
\hline
\end{tabular}




\begin{tabular}{llll}
\hline Amino acid (g/100g protein)* & Value & FAO/WHO pattern** & Chemical score *** \\
\hline Lysine & $5.37 \pm 0.20$ & 5.80 & $92.59+$ \\
Arginine & $6.29 \pm 0.30$ & 33.90 & \\
Total EAA & 37.77 & & \\
\hline
\end{tabular}

* Mean of three determinations $\pm \mathrm{SD}$ (on dry weight basis).

** Pattern for $2-5$ years old child

*** $\mathrm{g}$ of EAA in $100 \mathrm{~g}$ protein of the sample divided by the $\mathrm{g}$ of the same EAA in $100 \mathrm{~g}$ protein of the $\mathrm{FAO} / \mathrm{WHO}$ standard pattern $\times 100$.

+ the first limiting amino acid.

The results of the fractionation of the total lipid classes of CASKF are shown in (Figure 2). The total lipids included mainly of eight fractions of acylglycerol and nonacylglycerol fractions in addition to the polar lipid class located on the base line. Triacylglycerol class was found to be the maior fraction of CASK oil. The other classes can be arranged, based on their $\mathrm{Rf}$ as follows: monoacylglycerols, 1,2 and 2,3 diacylglycerols, sterols, 1,3 diacylglycerols, unknown, free fatty acids, triacylglycerols hydrocarbons and sterolesters based on the front line. The results obtained in the present study are more or less similar to that of other oil seed resources such as cantaloupe seeds [35], date pits [36], dehydrated mushroom flour [37], flaxseed [38] and okra seeds [39].

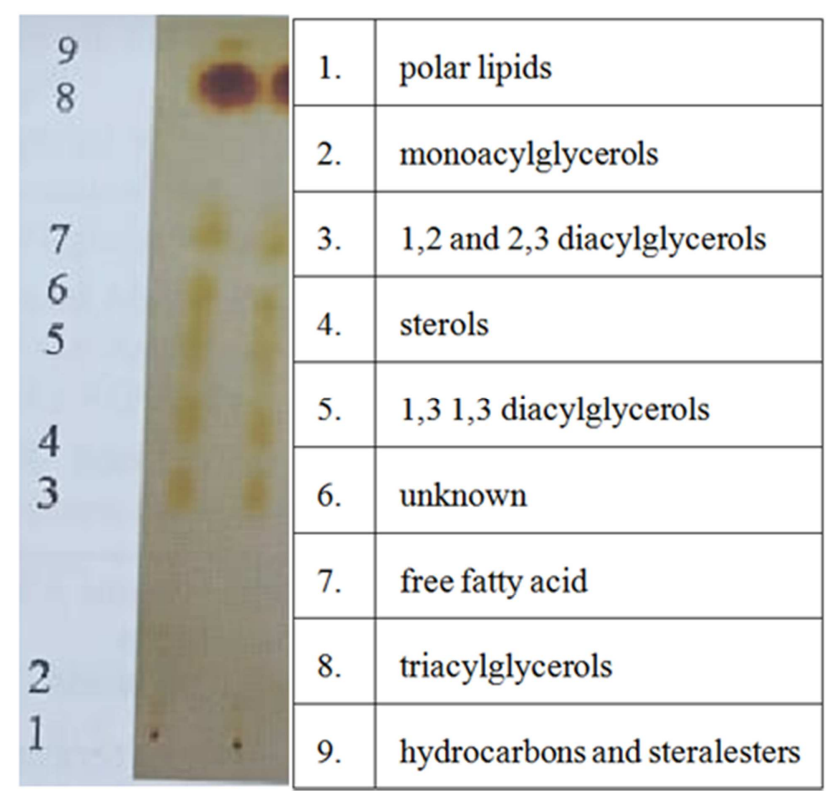

Figure 2. Thin layer chromatogram of total lipids of custard apple seed kernel oil.

Coating material: Silica gel G Merk type 60

Solvent System: petroleum ether: diethyl ether glacial acetic (70:30:2 v/v/v) Detection: Exposure to iodine vapour

The physiochemical characteristics of the oil extracted from CASKF are presented in Table 6 . The color of the crude oil was light yellow and smelled acceptable and liquid at room temperature and did not contain high free fatty acids (1.68 as\% oleic acid) and unsaponifiable matter (1.21\%). The results of the refractive index and the specific gravity obtained were within the standard of most crude vegetable oils [40]. The value of saponification in oil was slightly high
(189.21) and the value of iodine was low comparatively (90.55). Thus, this oil is categorized as semi-dry oil such as cottonseed, sunflower oil and maize. The value of peroxide in crude oil was low $\left(0.82 \mathrm{mEq} \mathrm{O} \mathrm{O}_{2} / \mathrm{kg}\right.$ oil $)$ indicated its high stability to retrogradation. Mariod et al. [26, 27] and Lokhande et al. [41] showed that the results of the present study are extremely similar in terms of physical and chemical properties of oil extracted from the seeds of Annona squamosa. Onimawo [42] Indicated that if was removed seamy odors from the oil of sour soup, was deodorized it can be valid as a source of oil for both domestic and industrial uses.

Table 6. Physicochemical properties of custard apple seed kernel oil.

\begin{tabular}{ll}
\hline Parameters & Value* \\
\hline Acid value $\mathrm{mg} \mathrm{KOH} / \mathrm{g}$ oil & $0.85 \pm 0.11$ \\
Free fatty acids as\% oleic acid & $1.68 \pm 0.20$ \\
Iodine value & $90.55 \pm 1.32$ \\
Unsaponifiable mater $(\%)$ & $1.21 \pm 0.30$ \\
Saponification value & $189.21 \pm 2.16$ \\
Peroxide value $\left(\mathrm{m} \mathrm{Eq} \mathrm{O}_{2} / \mathrm{kg}\right.$ oil) & $0.82 \pm 0.10$ \\
Refractive index at $25^{\circ} \mathrm{C}$ & $1.4668 \pm 0.10$ \\
Specific gravity at $25^{\circ} \mathrm{C}$ & $0.8175 \pm 0.06$ \\
Lovibondcolour $(1$ in.cell) & \\
Yellow & $35 \pm 0.0$ \\
Red & $3.5 \pm 0.01$ \\
Blue & $0.3 \pm 0.01$ \\
\hline
\end{tabular}

* Mean of three determinations \pm SD.

Fatty acid composition of CASK oil are presented in (table 7). The percentage of the unsaturated fatty acids was $72.25 \%$ of the total fatty acids. The main unsaturated fatty acids were oleic $(49.75 \%)$ followed by linoleic $(22.50 \%)$. On the other hand, the saturated fatty acids represented $27.75 \%$ of the total fatty acids. The saturated fatty acids were found to be composed of palmitic acid (15.06\%), followed by stearic acid $(11.63 \%)$ and trace amounts of C14:0, C 20:0 and C12:0. The existence of high content of unsaturated fatty acids especially oleic acid demonstrated to be a highly nutritious oil and can be used to decrease high level of blood cholesterol. As shown in (Table 7), the ratio of unsaturated to saturated fatty acids was 2.60. This ratio is quite similar to the common crude oil such as corn, cottonseed and sunflower seed oils.

In accordance with the results obtained here, Mariod et al. $[26,27]$ found that the fundamental fatty acids of Annona squamosa oil were C16:0, C18:0, C18:1 and C18:2. They stated that the extraction method did not impact the fatty acid structure. C18:1 was the most dominant fatty acid followed by $\mathrm{C} 18: 2$. On the other hand, they reported that $\mathrm{C} 16: 0$ and C18:0 acids exhibited the third and fourth highest fatty acid 
contents.

Acda [43] pointed out that saturated and unsaturated fatty acids identified from Annona squamosa seeds were biologically active ingredients responsible for the expulsion of certain insects. [44] Showed that the fatty acid composition of Annona squamosa L. seed kernels were C18:1 (47.4\%), C18:2 (22.9\%), C18:0 (13.6\%) and C16:0 (12.1\%). C18:1 and $\mathrm{C} 18: 2$ together constituted $70.3 \%$ of the total UFAs followed by the SFAs $(25.7 \%)$.

Table 7. Fatty acid composition (\% of total) of custard apple seed kernel oil.

\begin{tabular}{ll}
\hline Fatty acid & \% of total* \\
\hline C 12: 0 & $0.21 \pm 0.07$ \\
C 14: 0 & $0.52 \pm 0.05$ \\
C 16: 0 & $15.06 \pm 0.20$ \\
C 16: 1 & ND*** \\
C 18: 0 & $11.63 \pm 0.32$ \\
C 18: 1 & $49.75 \pm 0.95$ \\
C 18: 2 & $22.50 \pm 0.11$ \\
C 18: 3 & ND*** \\
C 20: 0 & $0.33 \pm 0.02$ \\
TSFAs (S) & 27.75 \\
TUFAs (U) & 72.25 \\
U/S ratio** & $2.60: 1.0$ \\
\hline
\end{tabular}

$*$ Mean of three determinations $\pm \mathrm{SD}$.

** Unsaturated/saturated ratio.

*** Not detected.

\section{Conclusions}

It can be concluded that custard apple seed kernel is a good source of crude oil and crude protein as well as some macroelements. Total essential amino acids was higher than that reported in FAOL WHO pattern. The extracted oil can be classified as a semi-dry oil. In general, custard apple seed kernel oil and its defatted flour appear to be useful in some food applications. Therefore, much research has to be done to explore digestibility, functional properties and the applications of custard apple seed kernel oil and defatted flour in some functional food products.

\section{References}

[1] Gajalakshmi, S., Divya, R., Deepika, V. D., Mythili, S. and sathiavelu, A., 2011. Pharmacological Activities of Annonasquamosa: A Review. International Journal of Pharmaceutical sciences Review and Research, 10: 24-29.

[2] Biba, V. S., Lakshmi, S., Dhanya, G. S. and Remani, p., 2013. Phytochemical analysis of Annonasquamosa seed extracts its. International Research Journal of Pharmaceutical and Applied Sciences, 3: 29-31.

[3] Badrie, N. and Schauss, A., 2009. Soursop (Annonamuricate L.): Composition, nutritional value, medicinal uses and toxicology. In: "Watson, R. R. and Preedy, V. D eds". Bioactive Foods in Promoting Health. Oxford: Academic Press. PP: 621-643.

[4] Morton, J. F., 1987. Soursop. In "Fruits of warm climates". Greenshoro, NC: Media Incorporated, pp: 75-80.
[5] Suresh, K., Manoharan, S., Panjamurthy, K. and Kavita, K., 2006. Chemo preventive and antilipidperoxidative efficiency of Annonasquamosa bark extract. Pakistan Journal of Biological Sciences, 9: 2600-2605.

[6] Ranjan, R. and Sahai, M., 2009. Coumarinolignans from the seed of Annonasquamosa Linn. E-Journal of Chemistry, 6: 518-522.

[7] Patel, J. D. and kumar, V., 2008. Annonasquamosa L.: phytochemical analysis and antimicrobial screening. Journal of Pharmacy Research, 1: 34-37.

[8] Vidyasagar, G. M. and Shivakumar, S. P., 2012. A comparative antimicrobial activity of methanolic root, leaf, seed cotyledon extracts of Annonasqamosa L. International Journal of Pharmacy and Pharmaceutical Sciences, 4: 289-292.

[9] Raj, D. S. andVennila, J. J., 2014. Antimicrobial activity of different polarity solvent extracts of Annonasquamosa leaves and seeds, International Journal of Microbiological Research, 1: $385-388$

[10] Koushik, O. S., Babu, P. S. and Karthikeyan, R., 2017. Phytochemical screening and evaluation of anti-fungal activity on the seed extracts of Annonasquamosa (L.) and Manilkarazapota (L.) CIB Tech Journal of Biotechnology, 6: 8-11.

[11] Hotti, S. R. and Hebbal, O. D., 2015. Biodiesel production process optimization from sugar apple seed oil (Annonasquamosa) and its characterization. Journal of Renewable Energy, 2015: 1-6.

[12] Kad, V. P., Jadhav, M. S. and Nimbalkar, C. A., 2016. Studies on physical, morphological and rheological properties of custard apple (Aannonasquamosa L). International Journal of Applied and Pure Science and Agriculture, 2: 140-147.

[13] AOAC, 2003. Official Methods of Analysis $16^{\text {th }}$ ed. Association of Official Analytical chemists International. Arlington, virginia, USA.

[14] Ranganna, S., 1977. Manual of Analysis of Fruit and Vegetable Products. Mc. Graw-Hill pub. Co. ltd., New Delhi.

[15] Naczk, M. and shahidi, F., 1989. The effect of methanol ammonia water treatment on the content of phenolic acids of canola. Food chem., 31: 159-164.

[16] Brand- Williams, W., Cuvelier, M. E. and Bersct, C., 1995. Use of a free radical method to evaluate antioxidant activity. LebensmittelWissenschaft und Technologie, 28: 25-30.

[17] Blauth, O. J., Chareinki, M. and Berbec., H., 1963. A new rapid method for determining tryptophan. Analytical Biochemistry, 8: 69-70.

[18] FAO/WHO, 1985. Energy and protein requirements. WHO Tech. Rep. Ser. No 724, World Health Organization, Geneva, Switzerland.

[19] Folch, J., lees, M. and Stanley, G. H., 1957. A simple method for the isolation and purification of total lipids from animal tissues. J. Biol. chem., 226: 497-509.

[20] Mangold, H. K. and Malins, D. C., 1960. Fractionation of fats, oils and waxes on thin layers of silicic acid. J. Am. Oil, Chem Soc., 37: 383-385.

[21] Rahma, E. H. and Abd El-Aal, M. H., 1988. Chemical characterization of peach kernel oil and protein: Functional properties, In-vitro digestibility and amino acid profile of the flour. Food chem., 27: 31-43. 
[22] Radwan, S. S., 1978. Coupling of two dimensional thin layer chromatography with gas chromatography for the quantitative analysis of lipid classes and their constituent fatty acids. $J$. Chromatog. Sci, 16: 538-542.

[23] American Oil Chemist's Society, 1983. Official Methods. Official and Tentative Methods of the American Oil Chemist's Society. $3^{\text {rd }}$ Ed., Walker, R. O. (Ed.) AOCS, Illinois, U.S.A.

[24] Steel, R. G. D. and Torrie, J. H., 1980. Principles and Procedures of Statistics, New York. McGraw- Hill Book comp. INC, New York, USA.

[25] Hassan, L. G., Mohammad, M. U., Umar, K. J. and Sokoto, A. M., 2008. Comparative study on the proximate and mineral contents of the seed and pulp of sugar apple (Annonasquamosa). Nigerian Journal of Basic and Applied Sciences, 16: 179-182.

[26] Mariod, A. A., Elkheir, S., Ahmed, Y, M. and Matthaus, B., 2010. Annonasquamosa and Catunaregamnilotica seeds, the effect of the extraction method on the oil composition. J. Am. Oil Chem. Soci., 87: 763-769.

[27] Mariod, A. A., Elkheir, S., Ahmed, Y. M and Matthaus, B. 2011. Review: Organic foods from Annonasquamosa (Gishta) and Catunaregamnilotica (Kirkir). Journal of Science and Technology, 12: 84-91.

[28] Shardul, K., Swati, J., Prajakta, K., Prafullachandra, T., Santosh, P. andArun, R., 2013. Proximate analysis of peel and seed of Annonasquamosa (Custard apple) fruit. Research Journal of Chemical Sciences, 3: 92-94.

[29] Chen, Y., Chen, Y., Shi, Y., Ma, C., Wang, X., Li, Y., Miao, Y., Chen, J. and Li, X., 2016. Antitumor activity of Annonasquamosa seed oil. Journal of Ethno pharmacology, 193: 362-367.

[30] Kothari, V. and Seshadri, S., 2010. Antioxidant activity of seed extracts ofAnnonasquamosaand Carica Papaya. Nutrition \& food science, 40: 403-408.

[31] Kadarani, D. K., Setyadjit, S., Seno, D. S. H. and Sakashih, E., 2013. Total phenol and antioxidant from seed and peel of ripe and unripe of Indonesian sugar apple (Annonasquamosa L.) extracted with various solvents IOSR Journal of pharmacy, 5: 20-25.

[32] Vijayaraghavan, K., Ali, S. M. and Maruthi, R., 2013. Studies on phytochemical screening and antioxidant activity of chromolaenaodorata and Annonasquamosa. International Journal of Innovative Research in Science, Engineering and Technology, 2: 7315-7321.

[33] Amoo, I. A., Emenike, A. E. and Akpambang, V. O. E., 2008. Compositional evaluation of Annona cherimoya (custard apple) fruit. Trends in Applied Sciences Research, 3: 216-220.
[34] Souza, F. T. C., Santos, E. R., da Cruz Silva, J., Valentim, I. B., Braga Rabelo, T. H., Farias de Andrade, N. R. and de Souza Silva, L. K., 2018. Production of nutritious flour from residue custard apple (Annonasquamosa L.) for the development of new products. Journal of Food Quality, 2018: $1-10$.

[35] Abdel-Nabey, A. A. and Attia, A. A., 1998. Physical properties and chemical composition of cantaloupe seeds as an unexploited source of vegetable oil. MenofiyaJ. Agric. Res., 23: 991-1007.

[36] Abdel-Nabey, A. A., 1999. Chemical composition and oil characteristics of date pits of six Egyptian cultivars. Alex. J. Agric. Res. 44: 127-141.

[37] Abu-Tor, E. S. M., Abdel-Nabey, A. A. and Sherin, F. A. Awd Allah (2012). Utilization of dehydrated mushroom flour in some functional food products. Alex. J. Fd. Sci.\& Technol., 9: $33-45$.

[38] Abdel-Nabey, A. A., Abu-Tor, E. S. M. and Abou-Gharbia, H. A., 2013. Chemical and technological studies on flaxseed (Linumusitatissimum) and its application in some functional food. J. Foods and Dairy Sci., Mansoura Univ., 4: 193-216.

[39] Abdel- Nabey, A. A. and Abou- Tor, E-S. M., 2014. Chemical composition and some physico -chemical characteristics of okra seeds and into extracted oil. Alex. J. Fd. Sci: \&Technol., 11: $11-19$

[40] Swern, D., 1979. Bailey's Industrial Oil and Fat Products. Vol. 1 , John Wiley and Sons, N.Y. $6^{\text {th }}$ Edition.

[41] Lokhande, A. R., Patil, V. S. and Wani, K. S., 2013. Study of diethanolamide from Custard apple seed oil (Annonasquamosa L.). International Journal of Engineering Research \&Technology, 2: 448-425.

[42] Onimawo, I. A., 2002. Proximate composition and selected physicochemical properties of the seed, pulp and oil of sour sop (Annonamuricata). Plant foods for Human Nutrition, 57: 165-171.

[43] Acda, M. N., 2014. Chemical composition of ethanolic seed extract of Annonasquamosa L. and A. muricata L.(Annonaceae) using G C- MS analysis. The Philippine Agricultural Scientist, 97: 422-426.

[44] Rana, V. S., 2015. Fatty oil and fatty acid composition of Annonasquamosa Linn. Seed kernels. International Journal of Fruit Science, 15: 79-84. 